\title{
Manajemen Stres dalam Mereduksi Stres Mahasiswa di Masa Learn from Home
}

\author{
Moesarofah \\ Universitas PGRI Adi Buana Surabaya \\ e-mail: moesarofah@unipasby.ac.id
}

Diterima: Mei 2021 | Dipublikasikan: Juni 2021

\begin{abstract}
ABSTRAK
Merebaknya pandemi Covid-19 membawa konsekuensi learn from home, namun pola belajar yang kurang terstruktur, rentang waktu belajar yang relatif panjang dan melelahkan, serta penyesuaian mahasiswa baru dari model pembelajaran direktif mengarah non direktif memberikan tekanan dan stress bagi mahasiswa. Tujuan PPM adalah melakukan pelatihan manajemen stres berkaitan dengan kondisi learn from home. Metode pelaksanaan secara daring. Peserta PPM adalah mahasiswa tahun pertama prodi Bimbingan dan Konseling, Fakultas Pedagogi dan Psikologi Unipa Surabaya. Tahapan manajemen stres mencakup pengenalan dan identifikasi stressor, menghubungkan stressor dengan sensasi pada pikiran dan tubuh, berlatih mindfulness, berlatih untuk membebaskan diri dari kondisi stres, dan memperkuat sisi positif yang individu miliki. Hasil pelatihan manajemen stres dirasakan efektif bagi peserta, diindikasikan sekitar $60 \%$ dari peserta merasakan kebermanfaat pelatihan manajemen stres, dan $80 \%$ dari peserta berharap akan adanya keberlanjutan program PPM. Keterbatasan penelitian adalah pelaksanaan kegiatan secara daring, sehingga diharapkan dapat ditindaklanjuti melalui pelatihan luring saat keadaan telah normal.
\end{abstract}

Kata Kunci: masa pandemi covid-19, pembelajaran dari rumah, manajemen stres

\begin{abstract}
The outbreak of the Covid-19 pandemic has consequences for learning from home, but the less structured learning patterns, the relatively long and tiring study time span, and the adjustment of new students from directive to non-directive learning models puts pressure and stress on students. The purpose of PPM is to conduct stress management training related to learn from home conditions. Online implementation method. PPM participants are first year students of Guidance and Counseling Study Program, Faculty of Pedagogy and Psychology, Unipa Surabaya. The stages of stress management include recognizing and identifying stressors, connecting stressors with sensations in the mind and body, practicing mindfulness, practicing to free oneself from stressful conditions, and strengthening the positive side that individuals have. The results of the stress management training were felt to be effective for the participants, it was indicated that around $60 \%$ of the participants felt the benefits of stress management training, and $80 \%$ of the participants hoped that the PPM program would continue. The limitation of the research is the implementation of online activities, so it is hoped that it can be followed up through offline training when things are back to normal.
\end{abstract}

Keywords: covid-19 pandemic, learn from home, stress management

\section{PENDAHULUAN}

Sejak teridentifikasi awal kasus pneumonia sebagai jenis baru corona virus (Covid-19) oleh China pada tanggal 07 Januari 2020, penambahan jumlah kasus Covid-19 berlangsung cepat dan menyebar ke luar wilayah Wuhan hingga negara lain (WHO, 2020). Kemudian tanggal 13 Juli 2020, WHO menginformasikan adanya 12.910 .000 kasus Covid-19 secara global, dengan angka kematian mencapai 561.000 dan terus bertambah jumlahnya hingga saat ini (Dong, Du, \& Gardner, 2020). Akibat dari pandemik yang meluas WHO pada bulan Maret 2020 mengumumkan bahwa wabah COVID-19 menjadi pandemi global (WHO, 2020) dan sejak saat itu pemerintah di berbagai negara mengambil langkah - langkah penanganan untuk melindungi warga melalui karantina wilayah dan penutupan akses transportasi. akibatnya langkah ini berpengaruh pada pembatasan aktivitas sehari - hari, termasuk kegiatan pendidikan (Peters et 
al., 2020).

Di Indonesia seiring merebaknya pandemi Covid-19, Pemerintah melakukan berbagai upaya pencegahan, salah satunya melalui surat edaran Kemendikti No 1 tahun 2020 tentang pencegahan penyebaran Corona di perguruan tinggi. Melalui surat edaran tersebut, Kemendikbud memberikan instruksi kepada perguruan tinggi untuk melakukan pembelajaran jarak jauh (Hendayana et al, 2020).

Dampak pandemi terhadap pembelajaran jarak jauh dianalisis oleh para peneliti dan disimpulkan bahwa perpindahan pembelajaran dari tatap muka ke arah pembelajaran jarak jauh berdampak signifikan pada kesehatan mental dan fisik mahasiswa (Raaper \& Brown, 2020). Penelitian lain tentang hubungan pembelajaran jarak jauh dan tingkat kecemasan dilakukan oleh Wang \& Zhao (2020) menunjukkan bahwa mahasiswa memiliki tingkat kecemasan lebih tinggi dibandingkan dengan populasi lain pada umumnya dengan prosentase mahasiswa kedokteran lebih tinggi dibandingkan mahasiswa non kedokteran, dan mahasiswa perempuan menunjukkan kecemasan lebih tinggi dari laki - laki (Wang \& Zhao, 2020). Begitu pula hasil penelitian Cao et al (2020) pada 7.143 mahasiswa yang terdampak masa pandemi, menunjukkan bahwa 0,9\% mahasiswa mengalami kecemasan berat, 2,7\% mengalami kecemasan sedang, dan 21,3\% mengalami kecemasan ringan (Cao et al., 2020).

Kondisi yang sama juga dialami oleh mahasiswa prodi Bimbingan dan Konseling (BK) Universitas PGRI Adi Buana Surabaya. Merespon fenomena pembelajaran jarak jauh, prodi BK mengadakan jajak pendapat kepada mahasiswa tahun pertama prodi BK. Pertimbangan dipilih mahasiswa tahun pertama, karena mereka adalah mahasiswa baru yang memasuki masa transisi dari model pembelajaran directive di SMA menuju pembelajaran nondirective di perguruan tinggi. Hasil jajak pendapat umumnya mengeluhkan tentang penerapan model pembelajaran dari rumah. Faktor - faktor yang menyebabkan pembelajaran jarak jauh dirasakan sulit bagi sebagian besar mahasiswa adalah kurangnya kesiapan mereka dalam mengatur pola belajar yang terstruktur sesuai tuntutan perkuliahan di masa new-normal dengan rentang waktu belajar yang relatif panjang dan berbeda, ketidakfokusan mahasiswa dalam melakukan proses pembelajaran jarak jauh, serta keterbatasan untuk mendapatkan penjelasan atau berdiskusi terkait tugas-tugas akademik.

Pembelajaran jarak jauh menjadi salah satu alasan yang mempersulit proses pembelajaran di masa new-normal (Nuere \& de Miguel, 2020), sehingga proses pembelajaran jarak jauh dirasa melelahkan dan membosankan bagi sebagaian besar mahasiswa. Selain itu pada sebagian mahasiswa yang termotivasi untuk menunjukkan prestasi dan keunggulan dalam persaingan akademik yang semakin meningkat, pembelajaran jarak jauh memunculkan terjadinya stress, terutama dialami oleh mahasiswa baru yang memasuki tahap penyesuaian.

Stressor yang muncul berkaitan dengan pembelajaran dari rumah berbeda secara individual. Persepsi mahasiswa terhadap stressor tidak semua bernilai negatif, karena ada sebagian mahasiswa yang lain memberikan penilaian positif terhadap stressor yang sama. Stressor bernilai positif ketika mampu direspon mahasiswa melalui perilaku positif yang mengarah pada tujuan akademik, sementara stressor dinilai negatif ketika mengarah ke perilaku agresif atau merusak harapan, dan nilai-nilai mahasiswa (Robotham \& Julian, 2006). Stres adalah proses interaksi dinamis antara individu dengan lingkungannya, di mana tuntutan lingkungan dinilai membebani kapasitas individu dan mengancam kesejahteraannya (Calvo \& Gutie'rrez-Garcı'a, 2020 dan Monroe \& Slavich, 2016). Dengan demikian respon stres tidak hanya bergantung pada keberadaan lingkungan, tetapi juga penilaian kognitif, psikologis, maupun strategi koping yang dilakukan individu (Lazarus \& Folkman, 1984).

Mempertimbangkan konsekuensi serius dari kondisi stress di masa pembelajaran dari rumah, sehingga dirasa penting dalam kegiatan Pengabdian Pada Masyarakan (PPM) Prodi BK Universitas PGRI Adi Buana di semester gasal tahun 2020 ini mengangkat tema "Manajemen Stres dalam Mereduksi Stres Mahasiswa di Masa Pembelajaran dari Rumah" sebagai strategi koping untuk mereduksi dampak stress dalam proses pembelajaran dari rumah. Bukti empiris menunjukkan bahwa manajemen stres lebih efektif dalam mengatasi masalah tertentu berkaitan dengan stres akademik [10]. Manajemen stres mengarah pada bagaimana mahasiswa berusaha 
untuk mengurangi stressor dalam lingkungan, mengubah penilaian terhadap potensi bahaya yang ditimbulkan oleh stressor, dan mengurangi ketegangan dari konsekuensi stressor tersebut. Peserta PPM adalah mahasiswa tahun pertama prodi BK Universitas PGRI Adi Buana Surabaya. Dipilih mahasiswa tahun pertama karena mereka berada dalam masa transisi, sehingga lebih rentan mengalami stres akademik dibandingkan mahasiswa tahun di atasnya.

\section{METODE PEIAKSANAAN}

Pelaksanaan kegiatan PPM dengan tema "Manajemen Stres di Masa Pembelajaran dari Rumah" dilakukan secara daring pada mahasiswa tahun pertama prodi BK Universitas PGRI Adi Buana Surabaya, pada tanggal 18 September 2020. Secara sistematis metode pelaksanaan kegiatan PPM digambarkan sebagai berikut.

1. Tahap Perencanaan

- Melakukan observasi dan jajak pendapat ke mahasiswa tentang permasalahan yang dihadapi berkaitan dengan kondisi pembelajaran dari rumah.

- Merumuskan tema dan tujuan kegiatan.

- Menganalisis hasil observasi terhadap permasalahan yang di hadapi mahasiswa prodi BK.

- Merancang materi tentang manajemen stres untuk mereduksi stres akademik mahasiswa di masa pembelajaran dari rumah.

2. Tahap Sosialisasi

- Mengundang mahasiswa prodi BK melalui whatsapp (WA) grup kelas untuk mengikuti pelatihan daring tentang manajemen stress untuk mereduksi stres akademik mahasiswa di masa pandemi sebagai konsekuensi pembelajaran dari rumah.

- Mengundang Dosen prodi BK melalui whatsapp (WA) grup dosen untuk turut berpartisipasi dalam kegiatan PPM

3. Tahap Pelatihan

Memberikan ceramah dan diskusi mengenai manajemen stress dalam mengelolah emosi negatif sebagai konsekuensi pembelajaran dari rumah. Materi manajemen stress mengadopsi dari strategi Biegel (Biegel, 2009), meliputi:

3.1 Mendefinisikan stress

- Mengenali stres apakah mengarah pada emosi yang tidak nyaman, sensasi fisik atau pikiran negatif.

- Mengenali stres baik (meningkatkan performansi, motivasi), atau stres buruk (menimbulkan luka hati)

3.2 Mendeteksi stres, apakah berpengaruh pada:

- Fisik $\rightarrow$ respon cenderung "melawan" atau "bertahan", mengenali bagian tubuh yang biasanya merasa stress.

- Emosi $\rightarrow$ putus asa atau ketakutan sehingga berpengaruh pada perilaku seperti sulit tidur.

- Pikiran $\rightarrow$ Pikiran positif membuat lebih bahagia dan rileks, atau pikiran negatif membuat tertekan.

3.3 Menghubungkan stressor dengan sensasi stres pada pikiran dan tubuh

3.4 Menuju perubahan 
- Menemukan stressor (pemicu stres)

- Berlatih mindfulness: memperhatikan setiap peristiwa dengan lebih sadar dan jelas

- Membebaskan diri dari stres dengan melepaskan suara hati negatif, menerima apa adanya tanpa ada penghakiman/penilaian baik atau buruk, benar atau salah

- Melakukan apa yang membuat individu bahagia $\rightarrow$ tidak menghabiskan energi untuk terpaku dengan satu peristiwa negatif

- Melihat kualitas positif yang individu miliki, dan memperkuat kualitas positif tersebut

3.5 Jeda sesaat sebelum bertindak/bereaksi terhadap pikiran, kata-kata maupun tindakan saat stres

3.6 Mengambil keputusan, dan tindakan bertanggung jawab atas konsekuensi yang akan terjadi

4. Tahap Evaluasi

- Membagikan form evaluasi PPM kepada peserta

- Menganalisis capaian PPM, melalui indikator: (1) kebermanfaatan materi PPM, (2) kejelasan pembicara dalam menyampaikan materi, (3) keberlangsungan acara PPM, (4) durasi kegiatan, (5) harapan dari peserta untuk kegiatan selanjutnya.

\section{HASIL KEGIATAN}

Tabel 1. Capaian Kegiatan PPM

\begin{tabular}{|l|l|l|l|}
\hline Indikator & Kurang & Cukup & Baik \\
\hline Kebermanfaatan materi PPM & $14 \%$ & $26 \%$ & $60 \%$ \\
\hline Kejelasan dalam menyampaikan materi & $7 \%$ & $13 \%$ & $80 \%$ \\
\hline Keberlangsungan acara PPM & $18 \%$ & $27 \%$ & $55 \%$ \\
\hline Durasi kegiatan & $13 \%$ & $10 \%$ & $77 \%$ \\
\hline Harapan peserta untuk kegiatan selanjutnya & $10 \%$ & $10 \%$ & $80 \%$ \\
\hline
\end{tabular}

Hasil pelatihan manajemen stres dirasakan efektif bagi peserta, diindikasikan dengan sekitar $60 \%$ dari peserta merasakan kebermanfaat pelatihan manajemen stres, dan $80 \%$ dari peserta berharap akan adanya keberlanjutan program PPM.

Persepsi mahasiswa tentang pembelajaran dari rumah dalam kurun waktu yang tidak pasti menjadi tantangan yang mengarah pada kelelahan dan stres. Beragam persepsi mahasiswa atas kondisi pandemi membawa konsekuensi pembelajaran dari rumah diwarnai oleh beragam atribusi individual. Ketika kondisi masih dapat dikontrol dan ada kepastian, maka hal ini cenderung dipersepsikan positif yang memotivasi mahasiswa untuk memperoleh manfaat, tetapi ketika pembelajaran dari rumah berkaitan dengan ketidakpastian dan tidak ada kendali serta sosial judgment yang bernilai negatif, maka maka kondisi ini berpotensi menurunkan performansi akademik mahasiswa (Houghton, Wu, Godwin, Neck, \& Manz, 2012).

Mahasiswa yang berada dalam tahap perkembangan masa remaja hingga dewasa awal lebih rentan terpapar stres daripada orang tua, karena pada usia muda kondisi psikologis mahasiswa relatif labil, munculnya konflik berbagai kepentingan, atau bahkan krisis keluarga berpengaruh 
terhadap respon mahasiswa terhadap stressor yang dihadapi. Mahasiswa dengan tingkat kesulitan ekonomi, sosial dan psikologis yang tinggi lebih berpeluang terpapar stres (Avison, 2016).

Efektivitas manajemen stres tercapai karena pada pelatihan ini mahasiswa berusaha untuk mengidentifikasi dan menemukan stressor, menghubungkan stressor dengan sensasi pada pikiran dan tubuh, serta berlatih untuk membebaskan diri dari kondisi stres dengan melepaskan suara hati negatif dan memperkuat sisi positif individu yang dimiliki.

\section{KESIMPULAN DAN SARAN}

Pelatihan manajemen stres di masa pembelajan dari rumah dinilai cukup efektif sebagai strategi koping yang positif. Mahasiswa merasakan kebermanfaat pelatihan, ketika mampu mengidentifikasi, menemukan, dan melepaskan diri dari stressor.

Persepsi mahasiswa tentang kondisi pembelajan dari rumah dipengaruhi oleh berbagai atribusi individual. Ketika stressor dapat dikontrol maka cenderung dipersepsikan positif. Sebaliknya ketika stressor tidak dapat dikontrol, maka stressor cenderung dipersepsikan sebagai suatu ancaman atau kerugian.

\section{UCAPAN TERIMA KASIH}

Ucapan terima kasih ditujukan kepada LPPM Unipa Surabaya sebagai penyandang dana untuk terselenggaranya kegiatan PPM Prodi BK, Fakultas Pedagogi dan Psikologi Unipa Surabaya dengan tema "Manajemen Stres di Era New Normal Covid-19"

\section{DAFTAR PUSTAKA}

Avison, W. R. (2016). Environmental Factors. In G. Fink (Ed.), Stress: Concept, Cognition, Emotion, and Behavior. Handbook of Stress (pp. 87-94). Elsevier Inc.

Biegel, G. M. (2009). Stress Reduction Workbook for Teens. Mindfulness skills to help you deal with stress. Canada: Raincoast Books.

Calvo, M. G., \& Gutie'rrez-Garci'a, A. 2016. Cognition and Stress. In G. Fink (Ed.), Stress: Concept, Cognition, Emotion, and Behavior. Handbook of Stress (pp. 139-144). Inc., Elsevier.

Cao, W., Fang, Z., Hou, G., Han, M., Xu, X., \& Dong, J. (2020). The psychological impact of the COVID-19 epidemic on college students in China. Psychiatry Research, 287. https://doi.org/https://doi.org/10.1016/j.psychres.2020.112934

Dong, E., Du, H., \& Gardner, L. (2020). An interactive web-based dashboard to track COVID-19 in real time. The Lancet Infectious Diseases, 20(5), 533-534. https://doi.org/10.1016/S1473-3099(20)30120-1

Hendayana, Y., Atmaja, D., Handini, D., Hidayat, F., Herlina, N., Nurita, N., Sari, R., Yunanto, D., Herlina, S., Fajri, M., Priandono, T., Larasati, C., Satria, G., Rouf, M. and Boediono, S., 2020. Buku Pendidikan Tinggi di Masa Pandemi COVID-19 Pembelajaran Perguruan Tinggi Dan Implementasi Merdeka Belajar Di Masa Pandemi Covid-19. Jakarta: Direktorat Jenderal Pendidikan Tinggi Kementerian Pendidikan dan Kebudayaan RI, p.14. 
Houghton, J. D., Wu, J., Godwin, J. L., Neck, C. P., \& Manz, C. C. (2012). Effective Stress Management: A Model of Emotional Intelligence, Self-Leadership, and Student Stress Coping. Journal of Management Education, 36(2), 220-238. https://doi.org/10.1177/1052562911430205

Lazarus, R. S., \& Folkman, S. (1984). Stress, appraisal, and coping. New York: Springer Publishing Company.

Monroe, S. M., \& Slavich, G. M. (2016). Psychological Stressors: Overview. In G. Fink (Ed.), Stress: Concept, Cognition, Emotion, and Behavior. Handbook of Stress (pp. 109-115). Inc., Elsevier.

Nuere, S., \& de Miguel, L. (2020). The Digital/Technological Connection with COVID-19: An Unprecedented Challenge in University Teaching. Technology, Knowledge and Learning, (0123456789). https://doi.org/10.1007/s10758-020-09454-6

Peters, M. A., Wang, H., Ogunniran, M. O., Huang, Y., Green, B., Chunga, J. O., Hayes, S. (2020). China's Internationalized Higher Education During Covid-19: Collective Student Autoethnography. Postdigital Science and Education, 2(3), 968-988. https://doi.org/10.1007/s42438-020-00128-1

Raaper, R., \& Brown, C. (2020). The Covid-19 pandemic and the dissolution of the university campus. Implications for student support practice. Journal of Professional Capital and Community, 5 (3/4), 343-349.

Robotham, D., \& Julian, C. (2006). Stress and the higher education student: A critical review of the literature. Journal of Further and Higher Education, 30(2), 107-117. https://doi.org/10.1080/03098770600617513

Wang, C., \& Zhao, H. (2020). The Impact of COVID-19 on Anxiety in Chinese University Students. Frontiers in Psychology, 11(May), 1-8. https://doi.org/10.3389/fpsyg.2020.01168 